\title{
Fish fauna of headwater streams that cross the Atlantic Forest of south São Paulo state
}

\author{
Mauricio Cetra ${ }^{1 *}$, Walter Barrella ${ }^{2}$, Francisco Langeani Neto ${ }^{3}$, Abílio G. Martins ${ }^{2}$, Bruno J. Mello ${ }^{1}$ and \\ Rodrigo S. Almeida ${ }^{1}$ \\ 1 Universidade Federal de São Carlos (UFSCar/Sorocaba), Departamento de Ciências Ambientais. Rodovia João Leme dos Santos, km110. CEP \\ 18052-780. Sorocaba, SP, Brazil. \\ 2 Pontifícia Universidade Católica (PUC/SP), Laboratório de Ecossistemas Aquáticos. Praça Dr. José Ermírio de Moraes, 290. CEP 18030-095. \\ Sorocaba, SP, Brazil. \\ 3 Universidade Estadual Paulista (UNESP/São José do Rio Preto), Departamento de Zoologia e Botânica, Laboratório de Ictiologia. Rua Cristóvão \\ Colombo, 2265. CEP 15054-000. São José do Rio Preto, SP, Brazil. \\ * Corresponding author. E-mail: mcetra@ufscar.br
}

\begin{abstract}
The fishes of the present study were collected in the headwater streams of the Sorocaba, Paranapanema and Ribeira de Iguape river basins during the dry period in 2010. A total of 2892 fishes, grouped in 53 species, were captured. The composition of the ichthyofauna captured in the streams of Sorocaba and Paranapanema river basin was greatly similar. On the other hand, the fish fauna of the streams of Ribeira de Iguape river basin were quite different from the ones captured in the others basins, with the occurrence of endangered species (Isbrueckerichthys epakmos and I. duseni) and exotic species (Misgurnus anguillicaudatus). The previous list of fish for the Sorocaba river basin increased with the addition of seven species of Characiformes, one Gymnotiformes and four Siluriformes.
\end{abstract}

\section{INTRODUCTION}

Despite knowing that no species of fish is totally extinct in the aquatic ecosystem of São Paulo state, we know that the small headwater streams are quickly and negatively being altered by anthropogenic interventions in their drainage basins (Castro and Menezes 1998). Some species that occur in these environments may have become extinct without prior scientific knowledge.

The area of interest is spatially heterogeneous characterized by diverse interacting patches ranging from human-dominated environments to conservation units. The basin of the Sorocaba river (Tietê river basin) is the most altered due to human activities, followed by the basin of Alto Paranapanema. On the other hand, the Ribeira de Iguape river basin has native vegetation and a high number of Conservation Units in a large portion of its area.

The Maciço de Piedade, on the Serra de Paranapiacaba has a high heterogenic relief, contributing to the formation of numerous small-size watercourses. In this region, drainage basin is separated topographically by the Serra de Paranapiacaba that represents a geographical barrier of the adjacent basins of Sorocaba, Paranapanema and Ribeira de Iguape rivers. This situation stimulated the present study, aiming at presenting the composition of the fish communities from the headwater streams belonging to the three hydrographic basins.

\section{Materials ANd Methods}

The hydrographic basin of the Sorocaba river and middle Tietê (UGRHI 10) is characterized by a well developed industrial pole, a deficit in vegetative covering in the areas of permanent preservation that range between 80 and $95 \%$ and a population density of about 140 inhabitants $/ \mathrm{km}^{2}$. Within this area lie the headwaters of the Sorocaba, Pirapora and Sarapuí rivers (IPT 2006). The headwaters of the Turvo river are inserted in the UGRHI 14 , corresponding to the hydrographic basin of the Alto Paranapanema that presents agricultural characteristics, a population density of around 30 inhabitants $/ \mathrm{km}^{2}$ with about $15 \%$ of native vegetation and headwaters covered by reforestation areas and natural forests (CETEC 1999). The UGRHI 11 includes the hydrographic basins of the Ribeira de Iguape and Litoral Sul. About $60 \%$ of its territory has native vegetation and it has a population density of about 15 inhabitants $/ \mathrm{km}^{2}$ (CETEC 2000). Given its physical conditions, it has the potential for conservation, with Conservation Units covering most part of its territory.

During the dry period in 2010 (July - November), we sampled the ichthyofauna in ten $100 \mathrm{~m}$-sections of streams in the Sorocaba river basin (Table 1), eight in the Paranapanema river basin (Table 2) and nine in the Ribeira de Iguape river basin (Table 3), totalizing 27 surveys carried out in the municipalities of Piedade, Pilar do Sul, Ibiúna, Tapiraí and Salto de Pirapora (Figure 1).

The ichthyofauna was sampled using electric fishing equipment (License $\mathrm{n}^{\circ}$ 13352-1 SISBIO/IBAMA/MMA and 260108-004.423/2010 SMA). The organisms collected were stored in the fish collection of the Ichthyology Laboratory, Zoology and Botany Department of the UNESP - São José do Rio Preto (DZSJRP 13618-13705). The Sorensen index (IS) was applied aiming at quantifying the similarity in the fauna composition between basins.

\section{RESUlTS AND DiscusSion}

A total of 2892 fish were captured, being 89\% smaller than $100 \mathrm{~mm}$ of total length (CT), grouped in 53 species $(81 \%<100 \mathrm{~mm}$ CT). The size agrees with comments by Castro and Menezes (1998) who, when referring to 
the fish fauna that live in the headwater streams of the hydrographic basins of São Paulo state, highlighted that the species are small-sized, limitedly distributed, have little or no commercial value and show a strong dependence on the riparian vegetation as a food source of non-native (alloctone) origin, for reproduction and protection.

In the streams of the Sorocaba and Paranapanema river basins 28 species were captured, while in the Iguape river basin 23 species were collected (Table 4). The specific composition of the streams of the Ribeira de Iguape river basin was quite different from the ones captured in the Sorocaba and Paranapanema basins ( $\mathrm{IS}_{\mathrm{RI}-\mathrm{S}}$ $=0.27$ and $\mathrm{IS}_{\mathrm{RI}-\mathrm{P}}=0.31$ ). On the other hand, there is a great similarity between the ichthyofauna of the streams of the Sorocaba and Paranapanema river basins ( IS $\left._{\text {S-P }}=0.68\right)$. Such results confirm our expectations, since the streams of the Sorocaba and Paranapanema river basin are part of the Alto Paraná basin, and this justifies the high similarity in the fauna composition. Furthermore, since the Ribeira de Iguape river basin is smaller than the Alto Paraná basin, observing less species richness in the streams of the Ribeira de Iguape basin is what one would expect according to the species-area relationship.

According to Oyakawa and Menezes (2011), 97 documented species currently exist in the Ribeira de Iguape river basin and close to $45 \%$ occur exclusively in this basin. This could be the cause of the endemism in these watercourses. The present study sampled only the headwater streams and 15 of the 23 species collected $(65 \%)$ were exclusive, something that could be a result of the stronger endemism in these watercourses. Furthermore, Isbrueckerichthys epakmos and I. duseni, species in danger of extinction according to Oyakawa et al. (2009), were captured in this study. It is also worth highlighting the capture of Misgurnus anguillicaudatus, an exotic species originally from Asia in a stream in the Ribeira de Iguape river basin. This species has a great past in ecological impacts following its introduction (Froese and Pauly 2011).

On the other hand, individuals of Phalloceros reisi, Hypostomus ancistroides, Rhamdia quelen, Hoplias malabaricus and Gymnotus silvius were collected in the streams of the three basins, reflecting their wide geographic distribution (Buckup et al. 2009, Oyakawa and Menezes 2011). Up to now, five species were captured that had an undefined taxonomic status, given that two are from the Characiformes order and three from the Siluriformes. This situation reflects the affirmation that, despite the Alto Paraná watercourses being the most well-studied in South America regarding the ichthyofauna, its richness (391 species) is far from representing reality, mainly taking into consideration the new descriptions coming from the streams and headwater environments (Langeani et al. 2007).

Aiming at updating the list of species published by Smith et al. (2007), that recorded the occurrence of 71 species for the Sorocaba river basin, seven Characiformes species are added: Astyanax paranae, Hyphessobrycon anisitsi, Piabina argentea, Characidium gomesi, Characidium oiticicai, Characidium zebra, Apareiodon ibitiensis; one Gymnotiformes: Gymnotus silvius; and four Siluriformes: Cetopsorhamdia iheringi, Pimelodella avanhandavae, Hypostomus variipictus, Trichomycterus iheringi. This addition is probably related to the collecting equipment since Smith et al. (2007) used gillnets, sieves and puçás (a sort of funnel net), while in the present study only electric fishing has been used and our samples were carried out solely in the headwater streams.

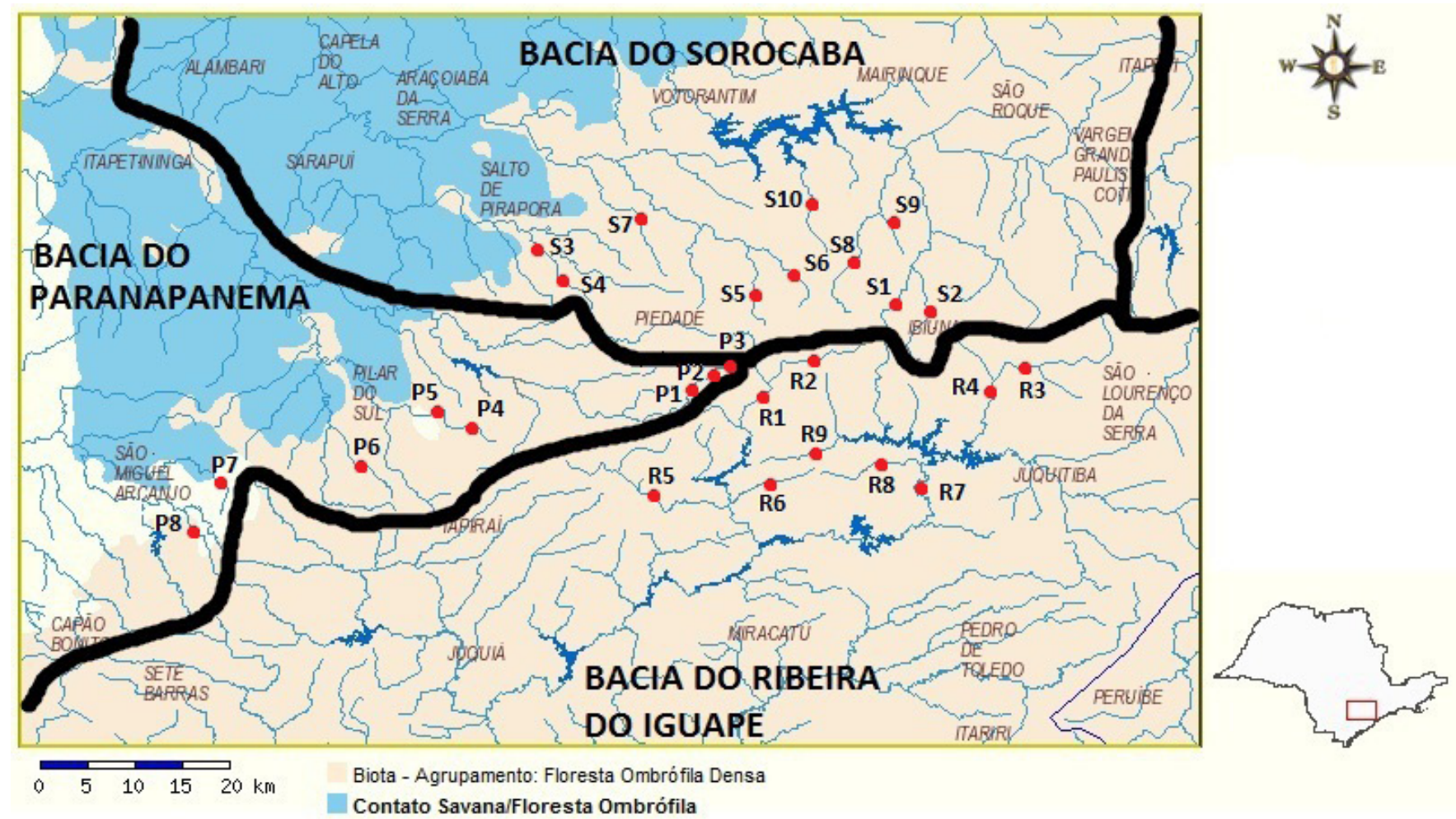

FIGURE 1. Boundary of the Sorocaba, Paranapanema and Ribeira de Iguape river basins and streams sampled (Font: http//sinbiota.cria.org.br/atlas/) 
TABLE 1. Geographic location of the sampled sections including its identification, municipality, sub-basin specification in the Sorocaba river hydrographic basin.

\begin{tabular}{llllll} 
ID & STREAM & MUNICIPALITY & SUB-BASIN & LONG & LAT \\
\hline S1 & Murundu & Ibiúna & Sorocabuçu & $47^{\circ} 15^{\prime} 24^{\prime \prime}$ & $23^{\circ} 48^{\prime} 40^{\prime \prime}$ \\
S2 & Paiol & Ibiúna & Sorocabuçu & $47^{\circ} 11^{\prime} 29^{\prime \prime}$ & $23^{\circ} 48^{\prime} 08^{\prime \prime}$ \\
S3 & Sarapuí & Salto de Pirapora & Sarapuí & $47^{\circ} 35^{\prime} 31^{\prime \prime}$ & $23^{\circ} 42^{\prime} 37^{\prime \prime}$ \\
S4 & Sarapuí & Salto de Pirapora & Sarapuí & $47^{\circ} 33^{\prime} 18^{\prime \prime}$ & $23^{\circ} 44^{\prime} 47^{\prime \prime}$ \\
S5 & Furnas & Piedade & Pirapora & $47^{\circ} 21^{\prime} 29^{\prime \prime}$ & $23^{\circ} 48^{\prime} 13^{\prime \prime}$ \\
S6 & Piraporinha & Piedade & Pirapora & $47^{\circ} 20^{\prime} 28^{\prime \prime}$ & $23^{\circ} 47^{\prime} 28^{\prime \prime}$ \\
S7 & Liberdade & Piedade & Pirapora & $47^{\circ} 27^{\prime} 00^{\prime \prime}$ & $23^{\circ} 43^{\prime} 02^{\prime \prime}$ \\
S8 & Salto & Piedade & Una & $47^{\circ} 17^{\prime} 13^{\prime \prime}$ & $23^{\circ} 46^{\prime} 26^{\prime \prime}$ \\
S9 & Cupim & Ibiúna & Una & $47^{\circ} 13^{\prime} 44^{\prime \prime}$ & $23^{\circ} 43^{\prime} 21^{\prime \prime}$ \\
S10 & Colégio & Ibiúna & Colégio & $47^{\circ} 18^{\prime} 33^{\prime \prime}$ & $23^{\circ} 41^{\prime} 59^{\prime \prime}$ \\
\hline
\end{tabular}

TABLE 2. Geographic location of the sampled sections including its identification, municipality, sub-basin specification in the Paranapanema river hydrographic basin.

\begin{tabular}{llllll}
\hline ID & STREAM & MUNICIPALITY & SUB-BASIN & LONG & LAT \\
\hline P1 & Turvo & Pilar do Sul & Turvo & $47^{\circ} 25^{\prime} 05^{\prime \prime}$ & $23^{\circ} 51^{\prime} 47^{\prime \prime}$ \\
P2 & Afluente Turvo & Piedade & Turvo & $47^{\circ} 24^{\prime} 07^{\prime \prime}$ & $23^{\circ} 51^{\prime} 38^{\prime \prime}$ \\
P3 & Turvo & Pilar do Sul & Turvo & $47^{\circ} 24^{\prime} 14^{\prime \prime}$ & $23^{\circ} 51^{\prime} 25^{\prime \prime}$ \\
P4 & Clarinho & Pilar do Sul & Pinhal & $47^{\circ} 42^{\prime} 46^{\prime \prime}$ & $23^{\circ} 53^{\prime} 22^{\prime \prime}$ \\
P5 & Claro Grande & Pilar do Sul & Pinhal & $47^{\circ} 42^{\prime} 47^{\prime \prime}$ & $23^{\circ} 53^{\prime} 23^{\prime \prime}$ \\
P6 & Pinhal & Pilar do Sul & Pinhal & $47^{\circ} 46^{\prime} 14^{\prime \prime}$ & $23^{\circ} 53^{\prime} 19^{\prime \prime}$ \\
P7 & Guarapu & S.M. Arcanjo & Turvo & $47^{\circ} 52^{\prime} 32^{\prime \prime}$ & $23^{\circ} 57^{\prime} 41^{\prime \prime}$ \\
P8 & Lageado & S.M. Arcanjo & Turvo & $48^{\circ} 01^{\prime} 00^{\prime \prime}$ & $23^{\circ} 59^{\prime} 47^{\prime \prime}$ \\
\hline
\end{tabular}

TABLE 3. Geographic location of the sampled sections including its identification, municipality, sub-basin specification in the Ribeira de Iguape river hydrographic basin.

\begin{tabular}{llllll}
\hline ID & STREAM & MUNICIPALITY & SUB-BASIN & LONG & LAT \\
\hline R1 & Grande & Piedade & Peixe & $47^{\circ} 19^{\prime} 40^{\prime \prime}$ & $23^{\circ} 50^{\prime} 36^{\prime \prime}$ \\
R2 & Ponte de Tábua & Piedade & Peixe & $47^{\circ} 17^{\prime} 05^{\prime \prime}$ & $23^{\circ} 49^{\prime} 39^{\prime \prime}$ \\
R3 & Vargens & Ibiúna & Juquiá & $47^{\circ} 14^{\prime} 29^{\prime \prime}$ & $23^{\circ} 51^{\prime} 18^{\prime \prime}$ \\
R4 & Vargens & Ibiúna & Juquiá & $47^{\circ} 14^{\prime} 36^{\prime \prime}$ & $23^{\circ} 51^{\prime} 46^{\prime \prime}$ \\
R5 & Areias & Tapiraí & Juquiá-Guaçu & $47^{\circ} 27^{\prime} 08^{\prime \prime}$ & $24^{\circ} 01^{\prime} 50^{\prime \prime}$ \\
R6 & afluente Juquiá-Guaçu & Ibiúna & Juquiá-Guaçu & $47^{\circ} 16^{\prime} 36^{\prime \prime}$ & $24^{\circ} 00^{\prime} 33^{\prime \prime}$ \\
R7 & afluente Juquiá-Guaçu & Ibiúna & Juquiá-Guaçu & $47^{\circ} 13^{\prime} 23^{\prime \prime}$ & $23^{\circ} 58^{\prime} 19^{\prime \prime}$ \\
R8 & Bonito & Ibiúna & Juquiá-Guaçu & $47^{\circ} 15^{\prime} 57^{\prime \prime}$ & $23^{\circ} 57^{\prime} 27^{\prime \prime}$ \\
R9 & Bagres & Ibiúna & Juquiá-Guaçu & $47^{\circ} 17^{\prime} 31^{\prime \prime}$ & $23^{\circ} 55^{\prime} 44^{\prime \prime}$ \\
\hline
\end{tabular}

TABLE 4. List of captured species in the headwater streams of the three hydrographic basins.

\begin{tabular}{|c|c|c|c|}
\hline & PARANAPANEMA & SOROCABA & RIBEIRA DE IGUAPE \\
\hline \multicolumn{4}{|l|}{ CHARACIFORMES } \\
\hline \multicolumn{4}{|l|}{ Characidae } \\
\hline Astyanax altiparanae Garutti and Britski, 2000 & $\mathrm{x}$ & $\mathrm{x}$ & \\
\hline Astyanax bockmanni Vari and Castro, 2007 & $\mathrm{x}$ & & \\
\hline Astyanax fasciatus (Cuvier, 1819) & $\mathrm{x}$ & $\mathrm{x}$ & \\
\hline Astyanax paranae Eigenmann, 1914 & $\mathrm{x}$ & $\mathrm{x}$ & \\
\hline Astyanax ribeirae Eigenmann, 1911 & & & $\mathrm{x}$ \\
\hline Astyanax sp. & & & $\mathrm{x}$ \\
\hline Astyanax sp2 & & & $\mathrm{x}$ \\
\hline Bryconamericus iheringi (Boulenger, 1887) & & $\mathrm{x}$ & \\
\hline Bryconamericus microcephalus (Ribeiro, 1908) & & $\mathrm{x}$ & \\
\hline Bryconamericus stramineus Eigenmann, 1907 & $\mathrm{x}$ & & \\
\hline Deuterodon iguape Eigenmann, 1907 & & & $\mathrm{x}$ \\
\hline Hyphessobrycon anisitsi (Eigenmann, 1907) & $\mathrm{x}$ & $\mathrm{x}$ & $\mathrm{x}$ \\
\hline Piabina argentea Reinhardt, 1867 & $\mathrm{x}$ & $\mathrm{x}$ & \\
\hline \multicolumn{4}{|l|}{ Crenuchidae } \\
\hline Characidium gomesi Travassos, 1955 & $\mathrm{x}$ & $\mathrm{x}$ & \\
\hline
\end{tabular}


TABle 4. Continued.

PARANAPANEMA SOROCABA RIBEIRA DE IGUAPE

Characidium lanei Travassos, 1967

Characidium oiticicai Travassos, 1967

$\mathrm{x}$

Characidium pterostictum Gomes, 1947

Characidium schubarti Travassos, 1955

Characidium zebra Eigenmann, 1909

$x$

Erythrinidae

Hoplias malabaricus (Bloch, 1794)

Parodontidae

Apareiodon ibitiensis Campos, 1944

Parodon nasus Kner, 1859

\section{GYMNOTIFORMES}

\section{Gymnotidae}

Gymnotus pantherinus (Steindachner, 1908)

Gymnotus silvius Albert and Fernandes-Matioli, 1999

SILURIFORMES

Callichthyidae

Callichthys callichthys (Linnaeus, 1758)

Corydoras aeneus (Gill, 1858)

\section{Heptapteridae}

Cetopsorhamdia iheringi Schubart and Gomes, 1959

Imparfinis mirini Haseman, 1911

Imparfinis borodini Mees and Cala, 1989

Phenacorhamdia tenebrosa (Schubart, 1964)

Pimelodella avanhandavae Eigenmann, 1919

Pimelodella transitoria (Ribeiro, 1907)

Rhamdia quelen (Quoy and Gaimard, 1824)

Loricariidae

Harttia kronei Miranda-Ribeiro, 1908

Hisonotus $\mathrm{sp} 1$

Hypostomus ancistroides (Ihering, 1911)

Hypostomus variipictus (Ihering, 1911)

Isbrueckerichthys duseni (Miranda-Ribeiro, 1907)

Isbrueckerichthys epakmos Pereira and Oyakawa, 2003

Neoplecostomus ribeirensis Langeani, 1990

Neoplecostomus cf. yapo Zawadzki, Pavanelli and Langeani, 2008

Neoplecostomus sp.

Rineloricaria pentamaculata Langeani and Araújo, 1994

Trichomycteridae

Ituglanis proops (Miranda-Ribeiro, 1908)

Trichomycterus iheringi (Eigenmann, 1917)

Trichomycterus cf. zonatus (Eigenmann, 1918)

$\mathrm{x}$

$\mathrm{x}-\mathrm{x}$

$\mathrm{X}$

$\mathrm{x}$

$\mathrm{X}$

Trichomycterus sp.

x $\quad x$

$\mathrm{x}$

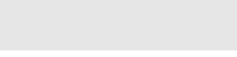

$x$
$x$

$x \quad x$

$\mathrm{x}-\mathrm{x}$

$\mathrm{x}$

$\mathrm{x}$

$\mathrm{X}$

$\mathrm{X}$

$\mathrm{x}$

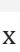

$x$

$\mathrm{x}$
$\mathrm{x}$
$\mathrm{x}$
$\mathrm{x}$

$\mathrm{x}$

$\mathrm{x}$

\section{CYPRINODONTIFORMES}

Poecilidae

Phalloceros reisi Lucinda, 2008

$\mathrm{X}$

$\mathrm{X}$

$\mathrm{X}$

SYNBRANCHIFORMES

Synbranchidae

Synbranchus marmoratus Bloch, 1795

$\mathrm{x}$

\section{PERCIFORMES}

\section{Cichlidae}

Australoheros facetus (Jenyns, 1842)

Geophagus brasiliensis (Quoy and Gaimard, 1824)

Geophagus iporangensis Haseman, 1911

$\mathrm{x}$

\section{CYPRINIFORMES}

Cobitidae

Misgurnus anguillicaudatus (Cantor, 1842) 
ACKNOWLEDGMENTS: We acknowledge FAPESP (Proc 2009/53056-8 e Proc 2004/00545-8) and CNPq (Proc 306.988/2008-9) for the financial support to carry out this research and reviewers for their valuable voluntary contribution.

\section{Literature Cited}

Buckup, P.A., N.A. Menezes and M.S. Ghazzi. 2009. Catálogo das espécies de peixes de água doce do Brasil. Rio de Janeiro: Museu Nacional. 195 p.

Castro, R.M.C. and N.A. Menezes. 1998. Estudo diagnóstico da diversidade de peixes do estado de São Paulo; p. 01-13 In C.A. Joly and C.E.M. Bicudo (ed.). São Paulo: FAPESP.

CETEC - Centro Tecnológico da Fundação Paulista de Tecnologia e Educação. 1999. Situação dos recursos hídricos do Alto Paranapanema UGRHI 14 - Minuta Preliminar do Relatório Técnico Final. Electronic database accessible at http://www.sigrh.sp.gov.br/ cgi-bin/sigrh_home_colegiado.exe?COLEGIADO=CRH\%2FCBHALPA\&TEMA=RELATORIO. Captured on 01 August 2011.

CETEC - Centro Tecnológico da Fundação Paulista de Tecnologia e Educação. 2000. Situação dos recursos hídricos do Ribeira de Iguape e Litoral Sul UGRHI 11 - Relatório Técnico Final. Electronic database accessible at http://www.sigrh.sp.gov.br/cgi-bin/sigrh_home_ colegiado.exe?COLEGIADO=CRH\%2FCBH-RB\&TEMA=RELATORIO. Captured on 01 August 2011.

Froese, R. and D. Pauly. 2011. FishBase. World Wide Web electronic publication version (06/2011). Electronic database accessible at www.fishbase.org. Captured on 01 August 2011.
IPT - Instituto de Pesquisas Tecnológicas. 2006. Plano de bacia da Unidade de Gerenciamento de Recursos Hídricos do Sorocaba e Médio Tietê (UGRH 10): Relatório Final. CETAE/LABGE 0 Electronic database accessible athttp://www.sigrh.sp.gov.br/ cgi-bin/sigrh_home_colegiado.exe?COLEGIADO=CRH\%2FCBHSMT\&TEMA=RELATORIO. Captured on 01 August 2011.

Langeani , F., R.M.C. Castro, 0.T. Oyakawa, O.A. Shibatta, C.S. Pavanelli and L. Casatti. 2007. Diversidade da ictiofauna do Alto Rio Paraná: composição atual e perspectivas futuras. $\quad B$ i o $t a$ Neotropica 7(3): 181-197.

Oyakawa, O.T. and N.A. Menezes. 2011. Checklist dos peixes de água doce do Estado de São Paulo, Brasil. Biota Neotropica, 11(1a): in press.

Oyakawa, T.O., N.A. Menezes, O.A. Shibatta, F.C.T.Lima, F. Langeani, C.S. Pavanelli, D.T.B. Nielsen and A.W.S. Hilsdorf. 2009. Peixes de água doce; 349-424 In P.M. Bressan, M.C.M. Kierulff and A.M. Sugieda (ed.). In Fauna ameaçada de extinção no Estado de São Paulo: vertebrados. São Paulo: Fundação Parque Zoológico de São Paulo. Secretaria do Meio Ambiente.

Smith, W.S., M. Petrere and W. Barrella. 2007. Fish, Sorocaba river subbasin, state of São Paulo, Brazil. Check List 3(3): 282-286.

RECEIVED: December 2011

ACCEPTED: March 2012

Published ONLINE: June 2012

EDITORIAL RESPONSIBILITY: Rubens Pazza 